\title{
ASPECTS REGARDING THE CUTTING CAPACITY OF DIAMOND DISCS USED IN THE FLAT GRINDING OF HARD GRANITE AND BASALT MINERAL MATERIALS
}

\author{
PETRE VALEA ${ }^{1 *}$ \\ ${ }^{1}$ Adjud Children's Club, Vrancea, Romania
}

\begin{abstract}
The paper presents how to determine the partial and global cutting capacity $(C C)$ based on technological evaluation criteria (sustainability, specific energy consumption, cutting forces, roughness) and technical economic criteria (grinding productivity and cost). The theoretical-experimental model that allows the determination of the global $C C$ for diamond discs takes into account the specific features of these super abrasive tools and the cutting process for flat grinding of hard mineral materials granite and basalt. Also, are presented the characteristics of diamond discs, the experimental stand and the factorial plans used in the experimental part.
\end{abstract}

Keywords: cutting capacity, diamond discs, flat grinding, evaluation criteria, durability, specific energy, cutting forces, roughness, grinding productivity, cost

\section{INTRODUCTION}

Throug experimental research carried out on hard mineral materials granite and basalt, it was posible to enrich the knowledge in the field of cutting capacity of diamond disc. In the literature and in workshop practice there are two concepts that refere to cutting and materials processed by cutting. The two concepts are cutting capacity and cutting machinability $[1,2,3]$.

According to the team of researchers from the Polytechnic University of Bucharest, the evaluation of the two concepts of cutting capacity and machinnability is done taking into account the same set of criteria: the criterion of wear or durability; the criterion of roughness, dimensional accuracy or shape; operational safety criteria; the criterion of vibration or acoustic emission etc. $[1,4,5]$.

The cutting capacity allows the establishment of the tool that best corresponds to the proposed purpose (technological process adopted), and the machinability by cutting allows the establishment of the material to be processed that has the best technical characteristics (hardness, structure, thermal conductivity etc.) that ensures conditions optimal requirements of the cutting process, in accordance with the main criteria adopted $[1,3]$.

The knowledge about the cutting capacity for a certain tool allows the choosing of the right tools in relation to the imposed technological objectives. Establishing the cutting capacity of the tools offers the possibility to choose the optimal cutting conditions, taking into account certain priority conditions, thus achieving optimal values for the prescribed technical and economic parameters and indicators. The problem of knowing the cutting capacity is important, both in the area of expensive and highly complex tools (gear tools, dimond abrasive stones/cubic boron nitride), and in the range normal tools with high consumption in industrial operation (drills, taps, lathe knives, mills, cutters brooches etc.) [1].

\footnotetext{
${ }^{*}$ Corresponding author, email: petrevalea@gmail.com

(C) 2021 Alma Mater Publishing House
} 
The evaluation of cutting capacity of the tools, but also of the machinability by cutting a material, will allow the technologist to make a correct choice for the cutting tool, to choose an optimal cutting regime, to choose the appropriate lubrication coolant etc. When the data on the cutting capacity of the tools and machinability by cutting a material are known, the total cost of processing can be assessed in advance considering the costs of construction and operation of tools, devices, machine tools and the time required for processing by cutting $[1,6]$.

The paper presents modality of the partial and global cutting capacity (CC) based on technological evaluation criteria (sustainability, specific energy consumption, cutting forces, roughness) and technical economic criteria (grinding productivity and cost). The theoretical-experimental model takes into account the specific characteristics of these super abrasive tools and the cutting process for the flat grinding of hard mineral materials granite and basalt allows the determination of the overall $\mathrm{CC}$ for diamond discs.

\section{EXPERIMENTAL SETUP}

\subsection{The principle of processing hard mineral materials with diamond discs and collecting experimental} data

Mineral materials (basalt, granite) that have a high hardness can be processed by conventional cutting with hard and very hard tools through the processes of cutting, turning, grinding and honing.

Grinding with diomand discs is considered to be a cutting with edges arranged randomly at the periphery of the diamond disc. It dependes on the interstices between the edges, the kinematic and geometric parameters of the tool $[4,5,7]$.

The main parameters that generally characterize the grinding process are: cutting forces; chip temperature; the quality (roughness) of the machined surface and the wear of the diamond disc. These parameters are found in the literature as criteria for assessing the machinabilitity of materials or criteria for assessing the cutting capacity of cutting tools $[1,6,8]$.

The principle of machining hard mineral materials with diamond discs is presented in Figure 1.

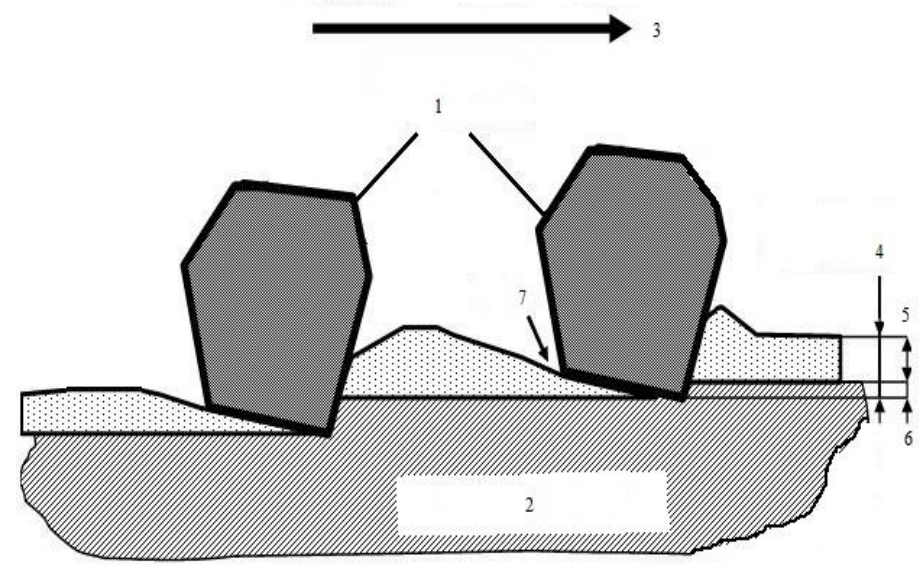

Fig. 1. The principle of processing hard mineral materials with diamond discs:

1 - diamond granules; 2 - mineral semi-finished product; 3 - disk rotation; 4 - heigt of prominence; 5 - tolerance; 6 - cutting depth; 7 - the tail [8].

In Figure 2 shows the image of the arrangement of the equipment for the acquisition of experimental data for processing on the RPO 200-AKS plan grinding machine [9].

\subsection{Superabrasive discs used}

2.2.1. Roughing grinding

Superabrasive discs used in the roughing of mineral materials (basalt, granite) are type 1A1 discs having the specifications:

- 1A1-175-10-3 D126 M75 H76.2; 
- $\quad$ AA1-200-10-3 D126 M75 H76.2;

- 1A1-300-15-4 D126 M75 H76.2.

For the grinding of roughing of mineral materials, it is recommended by the manufacturers of abrasive tools, in catalogs, to use diamond discs with D126 granulation, M metal binder and concentration 75 [10-12].

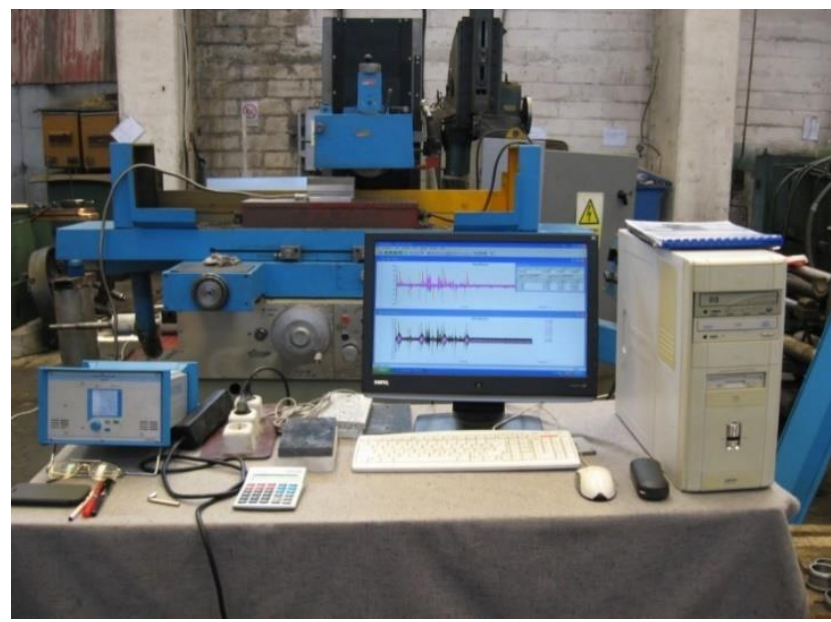

Fig. 2. Arrangement of the equipment for data aquisiton on the RPO 200-AKS plan grinding from SC Vrancart SA [8].

\subsubsection{Finishing grinding}

Superabrasive discs used in the finishing grinding of basalt, granite mineral materials are type 1A1 discs having the specifications:

- 1A1-175-10-3 D76 R75 H76.2;

- 1A1-200-10-4 D76 R75 H76.2;

- 1A1-300-15-4 D76 R75 H76.2.

For the finishing grinding of mineral materials, it is recommended by the manufacturers of abrasive tools, in catalogs, to use diamond discs with D76 granulation, R resinoid binder and concentration 75 [10-12].

\subsection{Tested mineral materials}

The test mineral materials for flat grinding on the RPO 200-AKS machine are [193]: granite and basalt. The granite mineral material is mined from the Iacobdeal-Macin quarry (characteristics according to STAS 6770-70). The basalt mineral material is mined from the Racos-Brasov quarry (characteristics according to STAS 6817-90).

Due to the special proprieties of products made of mineral materials, both those of natural origin and those that have undergone a primary processing (melting, sintering, casting mixed with an epoxy resin) they are used in industry as raw materials, but also as excellent substitues for components and parts of ferrous and non-ferous materials $[7,13,14,15]$.

The uses of granite and basalt in the machine building industry (machine tool frame, gearbox housings etc) make granite and basalt excellent replacements for solid and heavy parts that require vibration sability and high rigidity $[16,17]$.

\subsection{Scheme of processing and arrangement of experimental data collection equipment}

Figure 3 shows the computing equipment coupled to the Kistler amplifier used in experimental plans $2^{3}$ and $3^{1} \mathrm{x}$ $2^{2}$.

Preliminary tests estabilished the fields of the variation of parameters of cutting regime for the two factorial plans chosen for the realization of the experimental part. The levels of variation of the independent variables for the factorial experimental plan with $2^{3}$ experiments are presented in Table 1 . The levels of variation of the independent variables for the experimental plan $3^{1} \times 2^{2}$ experiments are presented in Table 2. 


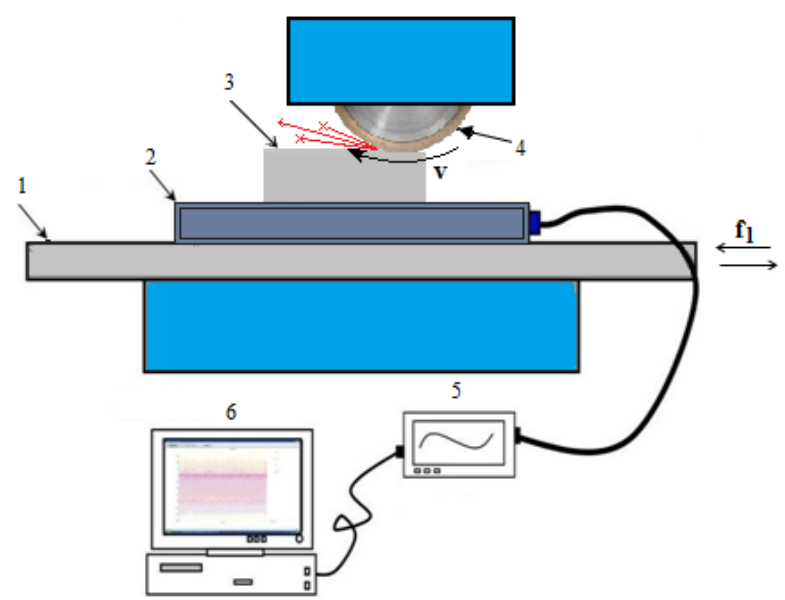

Fig. 3. Scheme regarding the arrangement of the experimental data collection equipment: $1-$ table of the RPO 200 AKS machine grinding; 2 - dynamometer Kistler; 3 - mineral workpiece; 4 - 1A1 shaped diamond disk; $f_{1}-$ the longitudinal advance of the table $[8,14,15,18]$.

Table 1 . Independent variables and test levels in the study of grinding in the factorial experiment $2^{3}[8,19,20]$.

\begin{tabular}{|c|c|c|c|c|}
\hline & Factors & $\begin{array}{l}\text { The cutting speed } \\
\qquad \begin{array}{c}v[\mathrm{~m} / \mathrm{s}] \\
\end{array}\end{array}$ & $\begin{array}{c}\text { The longitudinal } \\
\text { advance } f_{l}[\mathrm{~m} / \mathrm{min}]\end{array}$ & $\begin{array}{l}\text { The cuting depth } \\
a_{p}[\mathrm{~mm}]\end{array}$ \\
\hline \multicolumn{2}{|c|}{ Number of levels } & 2 & 2 & 2 \\
\hline \multirow{2}{*}{ Values } & Minimum /- & 27 & 2.775 & 0.01 \\
\hline & Maximum /+ & 31 & 4.446 & 0.02 \\
\hline
\end{tabular}

Table 2. Independent variables and test levels in the study of roughing and finishing grinding in factorial experiments $3^{1} \times 2^{2}[8,19,20]$.

\begin{tabular}{|c|c|c|c|c|}
\hline \multicolumn{2}{|c|}{ Factors } & $\begin{array}{c}\text { The cutting speed } \\
\qquad v[\mathrm{~m} / \mathrm{s}]\end{array}$ & $\begin{array}{l}\text { The longitudinal } \\
\text { advance } f_{l}[\mathrm{~m} / \mathrm{min}]\end{array}$ & $\begin{array}{c}\text { The cuting depth } \\
a_{p}[\mathrm{~mm}]\end{array}$ \\
\hline \multicolumn{2}{|c|}{ Number of levels } & 3 & 2 & 2 \\
\hline \multirow{3}{*}{ Values } & 1 & 27 & 2.38 & 0.01 \\
\hline & 2 & 31 & 4.08 & 0.03 \\
\hline & 3 & 47 & - & - \\
\hline
\end{tabular}

The following dependent variables of cutting process were determined: the cutting forces, evaluated by its three components: $F_{\mathrm{x}} ; F_{\mathrm{y}} ; \mathrm{F}_{\mathrm{z}}[\mathrm{N}]$; wear of abrasive discs by parametres $G, \varphi$ and $Q[\mathrm{~g} / \mathrm{min}]$ (where $G$ is grinding report, $\varphi$ is percentage of wear, $Q$ is grinding productivity); the roughess of the processed surfaces, evaluated by the parameter $R_{\mathrm{a}}[\mu \mathrm{m}]$ and the power consumption in grinding evaluated by the parameter $P[\mathrm{~kW}]$. The experimentally determined values were used to calculate the cutting capacity of diamond disks [21-23].

\section{CALCULATION OF CUTTING CAPACITIES FOR DIAMOND DISCS}

The overall cutting capacity evaluated on the basis of technological criteria (durability or wear, cutting forces, specific energy consumed/consumption, roughness of processed surfaces) as well as technical-economic criteria (productivity criterion and cost criterion) is a problem of optimization in different branches of machines construction.

3.1. Determination of cutting capacity based on the criterion of durability when grinding mineral materials The main criterion for assessing cutting capacity is considered durability. In practice, this criterion is most widely used in assessing cutting capacity. In order to highlight the criterion of durability of cutting tool, we consider the tool durability indicator. The determination of cutting capacity based on the durability and wear criterion is done by measuring the wear, respectively the durability in the imposed cutting condidions.

In practice, the cutting capacity assessed on the basis of durability can be expressed by the volume of chips removed by the tool until the wear criterion is reached, so the durability calculation ratio is [1]: 


$$
C A_{d V}=V_{\text {aschiat }}\left[\mathrm{mm}^{3}\right]
$$

where $V_{\text {as }}$ is the volume of chips removed $\left[\mathrm{mm}^{3}\right]$.

Table 3 shows the volume of chips removed when grinding granite $(\Delta t=80 \mathrm{~min})$ and basalt $(\Delta t=90 \mathrm{~min}) \mathrm{mineral}$ materials.

Table 3. Experimental results obtained in the research carried cut in the process of roughing grinding of hard

mineral materials, granite and basalt on the volume of chips removed from the tool (factorial plan $3^{1} \times 2^{2}$ ).

\begin{tabular}{|c|c|c|c|c|c|}
\hline \multirow{2}{*}{$\begin{array}{l}\text { Exp. } \\
\text { number }\end{array}$} & \multicolumn{3}{|c|}{ Cutting regime } & \multicolumn{2}{c|}{ The volume of the chips removed } \\
\cline { 2 - 6 } & $V[\mathrm{~m} / \mathrm{s}]$ & $f_{l}[\mathrm{~mm}]$ & $a_{p}[\mathrm{~mm}]$ & $V\left[\mathrm{~mm}^{3}\right]$ granit & $V\left[\mathrm{~mm}^{3}\right]$ bazalt $^{2}$ \\
\hline 8 & 31.00 & 4.08 & 0.03 & 131.92 & 299.88 \\
\hline
\end{tabular}

In general, the cutting capacity of the tool, assessed on the basis of durability, is measured directly by the actual cutting time between two sharpenings, so the calculation relationship of durability is [1]:

$$
C A_{d i}=T_{i}[\min ]
$$

where $T_{\mathrm{i}}$ is the effective cutting time between two sharpenings [min].

The durability of the tool can be calculated, depending on the parameters of the cutting regime and the actual cutting conditions, with the relation $[1,19]$ :

$$
T=C_{T} v^{z_{T}} f_{l}^{y_{T}} a_{p}^{x_{T}} \quad[\min ]
$$

where: $C_{T}$ is the coefficient of grinding; $v$ - cutting speed $[\mathrm{m} / \mathrm{s}] ; f_{l}$ - longitudinal advance $[\mathrm{m} / \mathrm{min}] ; a_{p}$ - cuting depth $[\mathrm{mm}] ; z_{T}, y_{T}, x_{T}$ - exponents of cutting speed, longitudinal advance and cuting depth.

From equations (2) and (3) results the equation (4) for defining the cutting capacity of diamond disck [1]:

$$
C A_{d T}=C_{T} v^{z_{T}} f_{l}^{y_{T}} a_{p}^{x_{T}}
$$

It results from equation (4) that the cutting capacity is influenced by the cutting speed $v[\mathrm{~m} / \mathrm{s}]$, followed by the longitudinal advance $f_{l}[\mathrm{~m} / \mathrm{min}]$ and the cutting depth $a_{p}[\mathrm{~mm}]$.

For example, when grinding the granite, the parameters of cutting regime will be considered: $v=31[\mathrm{~m} / \mathrm{s}], f_{l}=$ $4.446[\mathrm{~m} / \mathrm{min}], a_{p}=0.01[\mathrm{~mm}] ; C_{T}=30 ; z_{T}=0.9 ; y_{T}=0.8$ and $x_{T}=0.7$. Substituing in the equation (4) the value of cutting capacity obtained:

$$
C A_{d T}=30 \times 31^{0,9} \times 4.446^{0.8} \times 0.01^{0.7}=84.85 \mathrm{~min}
$$

For example, when grinding the basalt, the parameters of cutting regime will be considered: $v=31[\mathrm{~m} / \mathrm{s}], f_{l}=4.446$ [m/min], $a_{p}=0.01[\mathrm{~mm}] ; C_{T}=32 ; z_{T}=0.9 ; y_{T}=0.8$ and $x_{T}=0.7$. Substituting in the equation (4) the value of cutting capacity obtained:

$$
C A_{d T}=32 \times 31^{0.9} \times 4.446^{0.8} \times 0.01^{0.7}=90.50 \mathrm{~min}
$$

3.2. Evaluation of the overall cutting capacity of diamond discs used for flat grinding of mineral materials In order, to compare the technical performances of the three diamond discs: $D_{\text {ext }}=175 \mathrm{~mm} ; D_{\text {ext }}=200 \mathrm{~mm}$ and $D_{\text {ext }}=300 \mathrm{~mm}$ to choose the most suitable abrasive tool in the flat grinding process, it is necessary to evaluate their overall cutting capabilitiies. The assesssment of overall cutting capacity at several cutting regimes is possible based on the knowledge of the partial cutting capacities.

The relationship for determining the overall cutting capacity $C C$ based on the criteria: durability, specific energy consumed, respectively the roughness of the processed surfaces is [1]: 


$$
\mathrm{CA}=\left(\frac{\mathrm{CA} \mathrm{d}}{\mathrm{CA}_{\mathrm{dr}}}\right)^{\alpha_{\mathrm{d}}} \times\left(\frac{\mathrm{CA} \mathrm{e}}{\mathrm{CA}_{\mathrm{er}}}\right)^{\alpha_{\mathrm{e}}} \times\left(\frac{\mathrm{CA}}{\mathrm{CA}_{\mathrm{rr}}}\right)^{\alpha_{\mathrm{r}}}
$$

where $C A_{d}$ is the ability of partial cutting according to the criterion of sustainability; $C A_{e}$ is the capacity of partial cutting according to the specific consumption energy criterion; $C A_{r}$ - the ability of partial cutting according to the roughness criterion of the processed surfaces; $C A_{e d}$ - the cutting ability of the reference tool according to the sustainability criterion; $C A_{e r}$ - the cutting ability of the reference tool according to the roughness criterion of the processed surfaces; $C A_{r e}$ is the cutting ability of the reference tool according to the specific consumption energy criterion; $\alpha_{d}, \alpha_{e}$ and $\alpha_{r}$ - priority exponents.

The results of experiments and the calculation of the global capacities of diamond discs with: $D_{\text {ext }}=175 \mathrm{~mm} ; D_{\mathrm{ext}}$ $=200 \mathrm{~mm}$ and $D_{\text {ext }}=300 \mathrm{~mm}$ for the roughing of hard mineral materials at different cutting regimes are presented in Table 4.

Table 4. The overall cutting capacity of diamond discs: $D_{\text {ext }}=175 \mathrm{~mm}, D_{\text {ext }}=200 \mathrm{~mm}$ and $D_{\text {ext }}=300 \mathrm{~mm}$ for roughing grinding of hard mineral materials granite and basalt at different cutting regimes (factorial plan $3^{1} \mathrm{X}$ $\left.2^{2}\right)$

\begin{tabular}{|c|c|c|c|c|c|c|c|c|c|}
\hline \multicolumn{4}{|c|}{\begin{tabular}{|l|} 
The evaluation criterion \\
\end{tabular}} & \multicolumn{4}{|c|}{ The specific cutting energy } & \multicolumn{2}{|c|}{$\begin{array}{l}\text { The overall cutting } \\
\text { capacity } \%\end{array}$} \\
\hline \multirow{2}{*}{\multicolumn{4}{|c|}{$\begin{array}{l}\text { The priority exponent } \\
\text { Processed material }\end{array}$}} & \multicolumn{4}{|c|}{$\alpha_{\mathrm{e}}=1$} & \multirow[b]{2}{*}{ Granite } & \\
\hline & & & & \multicolumn{2}{|c|}{ Granite } & \multicolumn{2}{|c|}{ Basalt } & & Basalt \\
\hline \multicolumn{4}{|c|}{$\begin{array}{l}\text { Partial cutting capacities } \\
\text { Cutting regime }\end{array}$} & \multirow{2}{*}{$C A_{e}$} & \multirow{2}{*}{$\left(\frac{C A_{e}}{C A_{e r}}\right)^{\alpha_{e}}$} & \multirow[b]{2}{*}{$C A_{e}$} & \multirow{2}{*}{$\left(\frac{C A_{e}}{C A_{e r}}\right)^{\alpha_{e}}$} & \multirow[b]{2}{*}{$C A$} & \multirow[b]{2}{*}{$C A$} \\
\hline $\begin{array}{l}\text { Exp. } \\
\text { number }\end{array}$ & $\begin{array}{l}v \\
{[\mathrm{~m} / \mathrm{s}]}\end{array}$ & $f_{l}[\mathrm{~mm}]$ & $\left.a_{p} \mathrm{~mm}\right]$ & & & & & & \\
\hline 1 & 47.00 & 2.38 & 0.01 & 1.10 & 0.188 & 1.82 & 0.311 & 18.8 & 31.1 \\
\hline 2 & 47.00 & 2.38 & 0.03 & 1.01 & 0.172 & 1.24 & 0.211 & 17.2 & 21.1 \\
\hline 3 & 47.00 & 4.08 & 0.01 & 1.69 & 0.288 & 1.91 & 0.326 & 28.8 & 32.6 \\
\hline 4 & 47.00 & 4.08 & 0.03 & 1.27 & 0.271 & 1.83 & 0.312 & 27.1 & 31.2 \\
\hline 5 & 31.00 & 2.38 & 0.01 & 2.25 & 0.384 & 2.52 & 0.430 & 38.4 & 43 \\
\hline 6 & 31.00 & 2.38 & 0.03 & 1.88 & 0.321 & 1.97 & 0.336 & 32.1 & 33.6 \\
\hline 7 & 31.00 & 4.08 & 0.01 & 2.72 & 0.464 & 2.87 & 0.490 & 46.4 & 49 \\
\hline 8 & 31.00 & 4.08 & 0.03 & 2.41 & 0.411 & 2.87 & 0.490 & 41.1 & 49 \\
\hline 9 & 27.00 & 2.38 & 0.01 & 3.27 & 0.558 & 5.85 & 1 & 58.5 & 100 \\
\hline 10 & 27.00 & 2.38 & 0.03 & 3.25 & 0.555 & 4.94 & 0.844 & 55.5 & 84.4 \\
\hline 11 & 27.00 & 4.08 & 0.01 & 5.98 & 1.022 & 7.51 & 1.283 & 102.2 & 128.3 \\
\hline 12 & 27.00 & 4.08 & 0.03 & 4.68 & 0.800 & 5.23 & 0.894 & 80.0 & 89.4 \\
\hline
\end{tabular}

The results of experiments and the calculation of the global capacities of diamond discs with: $D_{\text {ext }}=175 \mathrm{~mm} ; D_{\text {ext }}$ $=200 \mathrm{~mm}$ and $D_{\text {ext }}=300 \mathrm{~mm}$ for the finishing of hard mineral materials granit and basalt at different cutting regis are presented in Table 5.

Table 5. The overall cutting capacity of diamond discs: $D_{\text {ext }}=175 \mathrm{~mm}, D_{\text {ext }}=200 \mathrm{~mm}$ and $D_{\text {ext }}=300 \mathrm{~mm}$ for finishing grinding of hard mineral materials at different cutting regimes (factorial plan $3^{1} \mathrm{X} 2^{2}$ ).

\begin{tabular}{|c|c|c|c|c|c|c|c|c|c|}
\hline \multirow{2}{*}{\multicolumn{4}{|c|}{\begin{tabular}{|c|} 
The evaluation criterion \\
The capacities of the reference tool
\end{tabular}}} & \multicolumn{4}{|c|}{ The specific cutting energy } & \multirow{3}{*}{\multicolumn{2}{|c|}{$\begin{array}{c}\text { The overall } \\
\text { cutting capacity } \\
\%\end{array}$}} \\
\hline & & & & \multicolumn{4}{|c|}{$C A_{e}=5.30$} & & \\
\hline \multicolumn{4}{|c|}{ The priority exponents } & \multicolumn{4}{|c|}{$\alpha_{\mathrm{e}}=1$} & & \\
\hline \multicolumn{4}{|c|}{ Processed material } & \multicolumn{2}{|c|}{ Granite } & \multicolumn{2}{|c|}{ Basalt } & \multirow{3}{*}{$\begin{array}{c}\text { Granite } \\
\text { CA }\end{array}$} & \multirow[t]{2}{*}{ Basalt } \\
\hline \multicolumn{4}{|c|}{ Cutting regime } & \multirow{2}{*}{$\mathrm{CA}_{\mathrm{e}}$} & \multirow{2}{*}{$\left(\frac{\mathrm{CA}_{\mathrm{e}}}{\mathrm{CA}_{\mathrm{er}}}\right)^{\alpha_{\mathrm{e}}}$} & \multirow{2}{*}{$\mathrm{CA}_{\mathrm{e}}$} & \multirow{2}{*}{$\left(\frac{\mathrm{CA}_{\mathrm{e}}}{\mathrm{CA}_{\mathrm{er}}}\right)^{\alpha_{\mathrm{e}}}$} & & \\
\hline $\begin{array}{l}\text { Exp. } \\
\text { number }\end{array}$ & $\begin{array}{l}v \\
{[\mathrm{~m} / \mathrm{s}]}\end{array}$ & $\begin{array}{l}f_{l} \\
\mathrm{~mm}]\end{array}$ & $a_{p}[\mathrm{~mm}]$ & & & & & & CA \\
\hline 1 & 47.00 & 2.38 & 0.01 & 1.93 & 0.394 & 7.42 & 1.400 & 36.4 & 14 \\
\hline 2 & 47.00 & 2.38 & 0.03 & 1.49 & 0.281 & 4.22 & 0.796 & 28.1 & 79.6 \\
\hline 3 & 47.00 & 4.08 & 0.01 & 2.79 & 0.526 & 7.20 & 1.358 & 52.6 & 135.8 \\
\hline 4 & 47.00 & 4.08 & 0.03 & 2.38 & 0.449 & 3.90 & 0.735 & 44.9 & 73.5 \\
\hline
\end{tabular}




\begin{tabular}{|l|c|c|c|c|c|c|c|c|c|}
\hline 5 & 31.00 & 2.38 & 0.01 & 4.43 & 0.835 & 5.64 & 1.064 & 83.5 & 106.4 \\
\hline 6 & 31.00 & 2.38 & 0.03 & 3.13 & 0.590 & 2.73 & 0.515 & 59 & 51.5 \\
\hline 7 & 31.00 & 4.08 & 0.01 & 6.80 & 1.283 & 5.50 & 1.037 & 128.3 & 103.7 \\
\hline 8 & 31.00 & 4.08 & 0.03 & 4.12 & 0.777 & 4.25 & 0.801 & 77.7 & 80.1 \\
\hline 9 & 27.00 & 2.38 & 0.01 & 12.40 & 2.339 & 6.74 & 1.271 & 233.9 & 127.1 \\
\hline 10 & 27.00 & 2.38 & 0.03 & 5.30 & 1 & 8.96 & 1.690 & 100 & 169.0 \\
\hline 11 & 27.00 & 4.08 & 0.01 & 9.02 & 1.701 & 9.63 & 1.816 & 170.1 & 181.6 \\
\hline 12 & 27.00 & 4.08 & 0.03 & 6.44 & 1.215 & 9.96 & 1.879 & 121.5 & 187.9 \\
\hline
\end{tabular}

Bellow are the results of experiments and the calculation of partial and global cutting capacities in the grinding of granite and basalt hard mineral materials, using the diamond disk $D_{\mathrm{ext}}=200 \mathrm{~mm}$ with the specifications: $1 \mathrm{~A} 1-200$ 10-3 D126 M75 H76.2 in experiment number 8, with parametres of cutting regime: $v=31 \mathrm{~m} / \mathrm{s} ; f_{l}=4.08 \mathrm{~m} / \mathrm{min}$; $a_{p}=0.03 \mathrm{~mm}$.

The results of the experiments and the calculation of the partial and global cutting capacities at the granite grinding are presented in Table 6.

Table 6. Overall cutting capacity of diamond disk $D_{\text {ext }}=200 \mathrm{~mm}$ when grinding roughing of granite (factorial plane $3^{1} \times 2^{2}$ ).

\begin{tabular}{|c|c|c|c|c|c|}
\hline The evaluation criterion & \multicolumn{2}{|c|}{ Durability } & \multicolumn{2}{|c|}{$\begin{array}{c}\text { The specific cutting } \\
\text { energy }\end{array}$} & $\begin{array}{c}\text { The overall } \\
\text { cutting capacity } \%\end{array}$ \\
\hline $\begin{array}{l}\text { The capabilities of the reference } \\
\text { tool }\end{array}$ & \multicolumn{2}{|c|}{$C A_{d r}=100$} & \multicolumn{2}{|c|}{$C A_{e r}=4.63$} & \\
\hline The priority exponents & \multicolumn{2}{|c|}{$\alpha_{d}=1$} & \multicolumn{2}{|c|}{$\alpha_{e}=0.5$} & \\
\hline $\begin{array}{l}\text { Partial cutting capacities } \\
\text { The disck }\end{array}$ & $\mathrm{CA}_{\mathrm{d}}$ & $\left(\frac{\mathrm{CA}_{\mathrm{d}}}{\mathrm{CA}_{\mathrm{dr}}}\right)^{\alpha_{\mathrm{d}}}$ & $\mathrm{CA}_{\mathrm{e}}$ & $\left(\frac{\mathrm{CA}_{\mathrm{e}}}{\mathrm{CA}_{\mathrm{er}}}\right)^{\alpha}$ & $\mathrm{CA}$ \\
\hline 1A1-200-10-3 D126 M75 H76.2 & 131.92 & 1.319 & 2.41 & 0.411 & 54.2 \\
\hline
\end{tabular}

The results of the experiments and the calculation of the partial and global cutting capacities at the basalt grinding are presented in Table 7.

Table 7. Overall cutting capacity of diamond disck $D_{\text {ext }}=200 \mathrm{~mm}$ when grinding roughing of basalt (factorial

\begin{tabular}{|c|c|c|c|c|c|}
\hline The evaluation criterion & \multicolumn{2}{|c|}{ Durability } & \multicolumn{2}{|c|}{$\begin{array}{c}\text { The specific cutting } \\
\text { energy }\end{array}$} & $\begin{array}{c}\text { The overall } \\
\text { cutting capacity } \%\end{array}$ \\
\hline The capacities of the reference tool & \multicolumn{2}{|c|}{$C A_{d r}=100$} & \multicolumn{2}{|c|}{$C A_{e r}=4.63$} & \\
\hline The priority exponents & \multicolumn{2}{|c|}{$\alpha_{d}=1$} & \multicolumn{2}{|c|}{$\alpha_{e}=0.5$} & \\
\hline $\begin{array}{l}\text { Partial cutting capacities } \\
\text { The disck }\end{array}$ & $\mathrm{CA}_{\mathrm{d}}$ & $\left(\frac{\mathrm{CA}_{\mathrm{d}}}{\mathrm{CA}_{\mathrm{dr}}}\right)^{\alpha_{\mathrm{d}}}$ & $\mathrm{CA}_{\mathrm{e}}$ & $\left(\frac{\mathrm{CA}_{\mathrm{e}}}{\mathrm{CA}_{\mathrm{er}}}\right)^{\alpha_{\mathrm{e}}}$ & CA \\
\hline 1A1-200-10-3 D126 R75 H76.2 & 299.88 & 2.998 & 2.87 & 0.490 & 146.9 \\
\hline
\end{tabular}

The results of experiments and the calculation of overall cutting capacities of diamond discs with $D_{\text {ext }}=175 \mathrm{~mm}$, respectiv $D_{\text {ext }}=200 \mathrm{~mm}$ for the grinding granite at different cutting regimes are presented in Table 8 .

The results of experiments and the calculation of overall cutting capacities of diamond discs with $D_{\text {ext }}=175 \mathrm{~mm}$, respectiv $D_{\text {ext }}=200 \mathrm{~mm}$ for the grinding basalt at different cutting regimes are presented in Table 9 .

\section{CONCLUSIONS}

The following conclusions can be drawn regarding the overall cutting capacity evaluated on the basis of technological criteria and technical-economic criteria for the grinding of hard mineral materials with diamond discs. 
Table 8 . The overall cutting capacity of diamond disc $D_{\text {ext }}=175 \mathrm{~mm}$ and $D_{\text {ext }}=200 \mathrm{~mm}$ for the granite hard mineral material grinding at different cutting regimes (factorial plan $2^{3}$ ).

\begin{tabular}{|c|c|c|c|c|c|c|c|c|c|c|}
\hline \multicolumn{4}{|c|}{ The evaluation criterion } & \multicolumn{2}{|c|}{ Durability } & \multicolumn{2}{|c|}{$\begin{array}{c}\text { The specific } \\
\text { cutting energy }\end{array}$} & \multicolumn{2}{|c|}{$\begin{array}{c}\text { The roughness of } \\
\text { the processed } \\
\text { surfaces }\end{array}$} & \multirow{3}{*}{$\begin{array}{c}\text { The } \\
\text { overall } \\
\text { cutting } \\
\text { capacity } \\
\%\end{array}$} \\
\hline $\begin{array}{l}\text { The } \\
\text { tool }\end{array}$ & acitie & of the & rence & $\begin{array}{r}C \\
D_{\text {ext }} \\
C \\
D_{\text {ext }}\end{array}$ & $\begin{array}{l}=38 \\
75 \mathrm{~mm} \\
=42 \\
00 \mathrm{~mm}\end{array}$ & \multicolumn{2}{|c|}{$C A_{e r}=4.63$} & \multicolumn{2}{|c|}{$C A_{r r}=1.73$} & \\
\hline \multicolumn{4}{|c|}{ The priority exponents } & \multicolumn{2}{|c|}{$\alpha_{d}=1$} & \multicolumn{2}{|c|}{$\alpha_{e}=0.5$} & \multicolumn{2}{|c|}{$\alpha_{r}=0.5$} & \\
\hline \multicolumn{4}{|c|}{$\begin{array}{l}\text { Partialettting capacities } \\
\text { Cutting regime }\end{array}$} & \multirow{2}{*}{$\mathrm{CA}_{d}$} & \multirow{2}{*}{$\left(\frac{\mathrm{CA}_{\mathrm{d}}}{\mathrm{CA}_{\mathrm{dr}}}\right)^{\alpha_{\mathrm{d}}}$} & \multirow{2}{*}{$\mathrm{CA}_{\mathrm{e}}$} & \multirow{2}{*}{$\left(\frac{\mathrm{CA}_{\mathrm{e}}}{\mathrm{CA}_{\mathrm{er}}}\right)^{\alpha_{\mathrm{e}}}$} & \multirow{2}{*}{$\mathrm{CA}_{\mathrm{r}}$} & \multirow{2}{*}{$\left(\frac{\mathrm{CA}_{\mathrm{r}}}{\mathrm{CA}_{\mathrm{rr}}}\right)^{\alpha_{\mathrm{r}}}$} & \multirow{2}{*}{$\mathrm{CA}$} \\
\hline $\begin{array}{l}\text { Exp. } \\
\text { nr. }\end{array}$ & $\begin{array}{l}v \\
{[\mathrm{~m} / \mathrm{s}]}\end{array}$ & $f_{l}[\mathrm{~mm}]$ & $\begin{array}{l}a_{p} \\
{[\mathrm{~mm}]}\end{array}$ & & & & & & & \\
\hline 1 & 27 & 2.775 & 0.01 & 39.30 & 1.03 & 1.15 & 0.534 & 1.74 & 1.002 & 55.11 \\
\hline 2 & 27 & 2.775 & 0.02 & 78.90 & 2.07 & 2.10 & 0.673 & 2.13 & 1.109 & 154.49 \\
\hline 3 & 27 & 4.446 & 0.01 & 57.3 & 1.50 & 2.05 & 0.665 & 2.41 & 1.180 & 117.70 \\
\hline 4 & 27 & 4.446 & 0.02 & 114.9 & 3.02 & 4.63 & 1 & 1.91 & 1.050 & 317.10 \\
\hline 5 & 31 & 2.775 & 0.01 & 44.7 & 1.06 & 1.77 & 0.618 & 2.28 & 1.148 & 75.20 \\
\hline 6 & 31 & 2.775 & 0.02 & 89.4 & 2.12 & 3.08 & 0.815 & 2.15 & 1.114 & 192.47 \\
\hline 7 & 31 & 4.446 & 0.01 & 65.1 & 1.55 & 3.08 & 0.815 & 1.73 & 1 & 126.32 \\
\hline 8 & 31 & 4.446 & 0.02 & 130.2 & 3.1 & 7.41 & 1.265 & 1.58 & 0.955 & 374.50 \\
\hline
\end{tabular}

Table 9. The overall cutting capacity of diamond disc $D_{\text {ext }}=175 \mathrm{~mm}$ and $D_{\text {ext }}=200 \mathrm{~mm}$ for the basalt hard mineral material grinding at different cutting regimes (factorial plan $2^{3}$ ).

\begin{tabular}{|c|c|c|c|c|c|c|c|c|c|c|}
\hline \multicolumn{4}{|c|}{ The evaluation criterion } & \multicolumn{2}{|c|}{ Durability } & \multicolumn{2}{|c|}{$\begin{array}{c}\text { The specific } \\
\text { cutting energy }\end{array}$} & \multicolumn{2}{|c|}{$\begin{array}{c}\text { The roughness } \\
\text { of the processed } \\
\text { surfaces }\end{array}$} & \multirow{3}{*}{$\begin{array}{c}\text { The } \\
\text { overall } \\
\text { cutting } \\
\text { capacity } \\
\%\end{array}$} \\
\hline The c & acitic & f the refe & nce tool & $\begin{array}{r}C A \\
D_{e x t}= \\
C A \\
D_{e x t}=\end{array}$ & $\begin{array}{l}=38 \\
75 \mathrm{~mm} \\
=42 \\
00 \mathrm{~mm}\end{array}$ & \multicolumn{2}{|c|}{$C A_{e r}=4.23$} & \multicolumn{2}{|c|}{$C A_{r}=1.70$} & \\
\hline \multicolumn{4}{|c|}{ The priority exponents } & \multicolumn{2}{|c|}{$\alpha_{\mathrm{e}}=1$} & \multicolumn{2}{|c|}{$\alpha_{\mathrm{e}}=0.5$} & \multicolumn{2}{|c|}{$\alpha_{\mathrm{r}}=0.5$} & \\
\hline \multicolumn{4}{|c|}{$\begin{array}{l}\text { Partial cutting capacities } \\
\text { Cutting regime }\end{array}$} & \multirow{2}{*}{$\mathrm{CA}_{\mathrm{d}}$} & \multirow{2}{*}{$\left(\frac{\mathrm{CA}_{\mathrm{d}}}{\mathrm{CA}_{\mathrm{dr}}}\right)^{\alpha_{\mathrm{d}}}$} & \multirow{2}{*}{$\mathrm{CA}_{\mathrm{e}}$} & \multirow{2}{*}{$\left(\frac{\mathrm{CA}_{\mathrm{e}}}{\mathrm{CA}_{\mathrm{er}}}\right)^{\alpha_{\mathrm{e}}}$} & \multirow{2}{*}{$\mathrm{CA}_{\mathrm{r}}$} & \multirow{2}{*}{$\left(\frac{\mathrm{CA}_{\mathrm{r}}}{\mathrm{CA}_{\mathrm{rr}}}\right)^{\alpha_{\mathrm{r}}}$} & \multirow[b]{2}{*}{$\mathrm{CA}$} \\
\hline $\begin{array}{l}\text { Exp. } \\
\text { nr. }\end{array}$ & $\begin{array}{l}v \\
{[\mathrm{~m} / \mathrm{s}}\end{array}$ & $f_{l}[\mathrm{~mm}]$ & $\begin{array}{l}a_{p} \\
{[\mathrm{~mm}]}\end{array}$ & & & & & & & \\
\hline 1 & 27 & 2.775 & 0.01 & 41.92 & 1.10 & 1.02 & 0.491 & 1.49 & 0.936 & 50.55 \\
\hline 2 & 27 & 2.775 & 0.02 & 84.16 & 2.21 & 1.68 & 0.630 & 1.76 & 1.017 & 141.59 \\
\hline 3 & 27 & 4.446 & 0.01 & 61.12 & 1.60 & 1.85 & 0.661 & 1.97 & 1.076 & 113.79 \\
\hline 4 & 27 & 4.446 & 0.02 & 122.56 & 3.22 & 4.23 & 1 & 1.77 & 1.020 & 328.44 \\
\hline 5 & 31 & 2.775 & 0.01 & 47.68 & 1.13 & 1.68 & 0.630 & 1.69 & 0.997 & 70.97 \\
\hline 6 & 31 & 2.775 & 0.02 & 95.36 & 2.27 & 2.84 & 0.819 & 2.08 & 1.105 & 205.43 \\
\hline 7 & 31 & 4.446 & 0.01 & 69.44 & 1.65 & 2.47 & 0.764 & 1.70 & 1 & 126.06 \\
\hline 8 & 31 & 4.446 & 0.02 & 138.88 & 3.30 & 8.47 & 1.415 & 1.23 & 0.850 & 396.90 \\
\hline
\end{tabular}

Based on the determination of the overall cutting capacity, the superiority of one superabrasive tool over another is established in the ligt of different criteria or restrictions.

The diamond disk with which the grinding of granite and basalt hard mineral materials with the lowest energy consumption is performed has the highest cutting capacity.

From the experimental study on the cutting capacity on the criterion of specific energy consumption in the grinding of the hard mineral materials granite and basalt, it is found that the value of the cutting capacity is higher for diamond discs with higher grain and metal binder, which leads us to the conclusion that the values of cutting capacity depend on the granulation and the binder of the disc used in the cutting process. 
Knowing the size of the main cutting force $F_{\mathrm{z}}[\mathrm{N}]$, it is posibile to determine the partial cutting capacity established on the basis of the criterion of the specific energy consumption at cutting.

Cutting tools that result in lower cutting forces lead to lower energy consumption and will have a higher cutting capacity.

There are large differences in the cutting capacity when grinding granite and basalt hard mineral materials with same disk, with different cutting regimes, which lead to the conclusion that the cutting capacity values depend on the parameters of the cutting regime and the processed mineral material.

Large diameter diamond discs $\left(D_{\text {ext }}=200\right.$, respectiv $\left.D_{\text {ext }}=300 \mathrm{~mm}\right)$ cut in better conditions, have a higher overall cutting capacity than small diameter discs and prove to be more economical.

In workshop practice is recommended for roughing grinding of mineral materials, the use of discs that have the specifications: 1A1-200-10-3 D126 M75 H76.2; 1A1-300-15-4 D126 M75 H76.2 and when finishing grinding of hard mineral materials, the use of superabrasive discs with specifications:1A1-200-10-3 D76 R75 H76.2; 1A1300-15-4 D76 R75 H76.2.

\section{REFERENCES}

[1] Enache, St., Strajescu, E., Tanase, I., Opran, C., Balici, M., Capacitatea de aschiere a sculelor, Editura Academiei Romane, Bucuresti, 2000.

[2] Strajescu, E., Tanase, I., Enache, St., Minciu, C., Interdependenta conceptelor de prelucrabilitatea materialelor si capacitatea de aschiere a sculelor aschietoare, Revista Tehnologii, Calitate, Masini, Materiale, Universitatea Politehica Bucuresti, Facultatea IMST, Catedra MUS, Editura Tehnica, Bucuresti, 1995, p. 227-242.

[3] Strajescu, E., Moraru, G.F., Metode de proiectare asistata a sculelor aschietoare, Universitatea Politehnica Bucuresti, 1999.

[4] Minciu, C., Predincea N., Bazele generarii prin aschiere a suprafetelor, Editura Bren, Bucuresti, 2007.

[5] Predincea, N., Croitoru, S.M, Bazele generarii suprafetelor pe masini-unelte, Editura Printech, Bucuresti, 2012.

[6] Croitoru, S.M., Bazele prelucrarii prin aschiere, Editura Politehnica Press, Bucuresti, 2015.

[7] Sandu, I.Gh., Generarea suprafetelor. Tratat, Editura Academiei, Bucuresti, 2008.

[8] Valea, P., Contributii privind îmbunatatirea conditiilor de aschiere la prelucrarea materialelor minerale, Teza de doctorat, Universitatea Politehnica Bucuresti, Facultatea IMST, 2019.

[9] Cartea tehnica a masinii de rectificat plan RPO 200-AKS, 2016.

[10] Catalog scule diamantate de la firma Diateh, Bucuresti, www.diateh-romania.ro (16.04.2021).

[11] Catalog scule diamantate de la firma Diasfin, Bucuresti, www.diasfin.ro (16.04.2021).

[12] Catalog scule diamantate de la firma Popa Tools, Codlea, www.popatools.ro (16.04.2021).

[13] Brabie, Gh., Samachis, I., Masini unelte. Bazele optimizarii solutiilor de proiectare, Editura Junimea, Iasi, 1995.

[14] Marinescu, I.D., Prelucrabilitatea prin rectificare folosind scule cu diamante romanesti, Teza de doctorat, Universitatea din Galati, Facultatea de Mecanica, 1993.

[15] Marinescu, I.D., Rectificarea pieselor din bazalt, Revista TCMM, nr. 2, Editura Tehnica, Bucuresti, 1987, p. 208-215.

[16] Popp, I.O., Some aspects regarding the static behavior of basalt in the machine building industry, MATEC Web Conf. 8th International Conference on Manufacturing Science and Education - MSE 2017, Trends in New Industrial Revolution, vol. 121, 2017, p. 1-6. https://www.researchgate.net/publication/335306639 (16.04.2020).

[17] Ciupan, M., Contributii privind proiectarea unor componente structurale din materiale compozite pentru masini-unelte moderne, Teza de doctorat, Universitatea Tehnica din Cluj-Napoca, 2020.

[18] Bulea, H., Tehnologia prelucrarii materialelor nemetalice si compozite, vol. 1, Editura Universitatii Transilvania, Brasov, 2005.

[19] Vlase, A., Balan, I.R., Vlase, B.G., Proiectarea tehnologiilor pe masini de rectificat, Editura Printech, Bucuresti, 2011.

[20] Dumitras, C., Opran, C., Prelucrarea materialelor compozite, ceramice si minerale, Editura Tehnica, Bucuresti, 1994.

[21] Zhang, D.K., Li, C., Jia, D., Zhang, Y., Investigation into engineering ceramics grinding mechanism and the influential factors of the grinding force, International Journal of Control and Automation, vol. 7, no. 4, 2014 , p. 19-34. 
[22] Shen, J., Hitoshi, W.L., Xu, O.X., Surfaces formation of precision ELID grinding rock minerals, Towards Synthesis of Micro-/Nano-systems, Springer, London, 2007.

[23] Kenda, J., Kopac, J, Diamond tools for machining of granite and their wear, Journal of Mechanical Engineering, vol. 55, no. 12, 2009, p. 775-780. 